\title{
On Lars von Trier, Enfant Terrible of Danish Art Film
}

\author{
By Mette Hjort \\ Fall 2011 Issue of KINEMA

\section{THE PROBLEM WITH PROVOCATION: ON LARS VON TRIER, ENFANT TERRIBLE OF DANISH ART FILM}

Anyone interested in contemporary art is likely to have spent a good deal of time pondering the nature and role of artistic provocation. Provocation as a crucial feature of artistic practice was largely unknown before 1800 (Walker 1999: 1). The idea of 'shocking the recipient' was, however, 'a dominant principle of artistic intent' for members of the various avant-garde movements that emerged in the early decades of the $20^{\text {th }}$ century (Peter Bürger, cited in Walker: 2), and at this point the provocateur is a well-known and even expected figure in the landscape of art. It is not difficult to think of examples of artworks that are self-evidently about creating a sense of outrage. Let me mention just a few well-known works that prompted a public outcry: Rick Gibson's Human Earrings (1985), which consists of a mannequin's head from which dangle earrings made with twelve-week-old freeze dried foetuses (Walker: 150); Piss Christ (1989) by the Honduran and Afro-Cuban American artist Andres Serrano whose red-tinged photograph depicts a crucifix submerged in (the artist's) urine; Vanitas: Flesh Dress for an Albino Anorectic (1991) by Canadian Jana Sterbak was exhibited, among other places, at the National Gallery in Ottawa in 1991. Made with 50 pounds of raw beef, the dress was displayed on a hanger alongside a photograph of a woman wearing it. An enactment of decay, this work involved the replacing of decomposed meat with new meat after six weeks. In 1971 performance artist Chris Burden had himself shot by an assistant, the very shooting becoming the work Shoot. With roots traceable to Viennese Actionism, Otto Muehl, Hermann Nitsch, and the 'AA Kommune', Yugoslavian filmmaker Dušan Makavejev's Sweet Movie (1974) features sexually provocative scenes cast in quasi-political terms.

It is not difficult to imagine the sense of outrage that these works provoked. The controversies were of course largely predictable and their eruption can legitimately be said to have contributed to the realization of the artists' intentions, which were clearly provocative, in the sense of controversy-seeking, in each and every case.

While provocation may be taken up in order to pursue such properly artistic goals as formal innovation or the fostering of creative attitudes, it is clear that in many cases the strategy in question is linked to intentions that are far more pragmatic in their thrust. Provocation generates attention and discussion and thus has the potential to function as a highly effective publicity device. If this has always been true, it is especially so in an era shaped by the accelerated processes of communication that digital technologies support. In an insightful piece titled 'Reviewing Antichrist' (focusing on critics' responses to Danish filmmaker Lars von Trier's 2009 film), Rod Stoneman (2009) clearly suggests that certain art critics feed the accelerative processes in question. In the self-promoting provocative antics of the 'European arthouse filmmaker', the critic finds a platform for another version of 'ego performance,' for provocations that are similar in ilk. The point, Stoneman rightly notes, is that both displays are mutually reinforcing.

In cases where an intent to generate strong negative emotions on the part of specific individuals and groups is present, a pragmatically oriented form of provocation becomes an interpersonal strategy. At times the point of such an interpersonal strategy appears to be ego-driven, making it the equivalent of a marketing tool. In other cases, goals extending well beyond the individual seem to be at stake, although they may be pursued in ways that are ultimately incoherent. Whether such goals are to be understood primarily in positive terms - as involving, for example, the unsettling or exposing of ultimately superficial values and pseudo-harmonies - or in largely negative terms - as involving the infliction of harm on, or the promoting of harmful attitudes towards specific groups - can only be determined on a case by case basis.

In the contemporary world of art cinema, Lars von Trier is a ready candidate for the title 'provocateur par excellence.' Over the course of a by-now long career as a filmmaker von Trier has systematically engaged in provocations spanning a wide range of types. Von Trier's provocative films are themselves the result of a philosophy of creativity that emphasizes provocation, or, rather, self-provocation. According to von 
Trier and Thomas Vinterberg, the rules governing Dogme 95 were, for example, formulated in accordance with the idea of proscribing the filmmakers' preferred artistic practices, as a form of reflexive provocation (Hjort 2003: 34). Cinematographer Anthony Dod Mantle, who has collaborated with von Trier on most of his films, sees the Danish filmmaker as 'pushing film language, always, always. [...] And this is provocative (emphasis added) and it's a privilege to be there. It encourages me to be naughty, to play around.'(1) The DVD bonus featurette titled The Evil of Woman is devoted to the historical research on attitudes towards women that was carried out in connection with the making of Antichrist. Citations from Aristotle ('The female animal is as it were a mutilated male' [De Generatione Animalium]), Friedrich Nietzsche ('When a woman has scholarly inclinations then something is usually wrong with her sexuality' [Beyond Good and Evil]), and early Church father Tertullian ('You are the port and gate of the devil. You are the first of God's law' [Women's Apparel]) feature prominently in the 'making of' film. Referring to the passages collected by his researcher, von Trier describes his filmmaking approach as follows: 'I pick up some research materials that are provoking me. That is all these materials are of course provoking me because for me it is nonsense. But I like it [sic; the provocative materials] to be in the film because it [sic] opens up a discussion and I am trying to do it as convincingly as I can.'

The content of von Trier's films - their suggested themes and meanings - is often provocatively at odds with what the filmmaker thinks of as politically correct views about women, race, sexuality, power, exploitation, and oppression. Articulating the filmmaker's self-understanding for him, Willem Dafoe puts the point as follows in the context of a press conference focusing on Manderlay at Cannes: von Trier 'abhors a comfortable political correctness. ${ }^{(2)}$ Former Zentropa producer Vibeke Windeløv describes Manderlay, a film about a slave plantation, as 'very provocative (emphasis added) in the way it deals with its subject matter.'(3) As these glimpses into the production process suggest, von Trier has consistently contributed to an auteurist discourse in which the concept of provocation occupies a central role. His meta-cultural statements about his films, to use Greg Urban's term (2001), are often willfully provocative, as even the most cursory survey of accounts of his appearances at the Cannes film festival over the years makes clear. When Antichrist premiered at Cannes in 2009, von Trier answered British journalist Baz Bamigboye's insistent demand that he justify the making of the film as follows: 'It's the hand of God, I'm afraid. And I am the best film director in the world. I'm not sure God is the best god in the world' (Stoneman 2009).

The bristling exchange between von Trier and Bamigboye expresses two very different views on provocation. With his call for an account of why the director felt compelled to make Antichrist, the journalist signalled an awareness of various kinds of harm potentially resulting from a film focusing, among other things, on the internalization of extreme misogyny. In addition to the provocative references to God, quoted above, von Trier's response to Bamigboye made use of the following lines of defence: pointing out that he rejected the very idea of his being called on to justify his film; identifying the journalists attending the press conference as his guests and, by implication, as bound by civility ruling out confrontational questioning; describing the film as a purely personal undertaking: 'I haven't done it for you or an audience.' The exchange in question is included in the DVD bonus featurette titled 'Chaos Reigns at the Cannes Film Festival,' which mirrors the title of Chapter 2 in the film, 'Pain (Chaos Reigns).' In the mind of a self-styled provocateur the provoked response to a provocative film is not unwelcome, for controversy is always attention-grabbing.

That there are limits to what can be tolerated in the name of (self-) provocation and that cinematic provocations can have unintended harmful and even deadly consequences was underscored by events in France and Norway in the Spring and Summer of 2011. Let us begin with the events in France, which highlight the limits of the strategy of provocation and of humour's capacity to neutralize offensive comments. At the Cannes film festival, von Trier described himself as a Nazi in response to a question about Melancholia, thereby prompting an immediate reprimand from festival organizers in the form of an official 'persona non grata' designation. Von Trier's unacceptable pronouncements were cited as follows by The Guardian's Charlotte Higgins, who, tellingly, chose to title her piece 'Lars von Trier provokes (emphasis added) Cannes with "I'm a Nazi" comments' (2011):

I thought I was a Jew for a long time and was very happy being a Jew .... Then it turned out that I was not a Jew ... I found out that I was really a Nazi which also gave me some pleasure. What can I say? I understand Hitler. He did some wrong things, absolutely, but I can see him sitting there in his bunker at the end. ... I sympathise with him, yes, a little bit. But come on, I 
am not for the second world war, and I am not against Jews. I am very much for Jews; well not too much because Israel is a pain in the ass. But still, how can I get out of this sentence? [...] OK, I'm a Nazi.

A full quote, without ellipses, would show that von Trier made reference, in the midst of his provocative ramblings about Jews, Nazis, and Hitler to fellow Zentropa filmmaker Susanne Bier, who is Jewish: 'I am not against Jews. Not even Susanne Bier. That was also a joke.(4) It would also show von Trier expressing great admiration for Albert Speer; and suggesting that to be German is to be a Nazi.

In the summer of 2011 von Trier once again drew attention, this time on account of a link that had been established between the content of his cinematic provocations and real life. On July $22^{\text {nd }}, 2011$ Norwegian right-wing extremist Anders Behring Breivik first detonated a car bomb in the government area of Oslo and then conducted a murderous shooting spree on the island of Utøya where the Labour Party was hosting its annual youth camp. Fuelled by hostility towards immigrants and multiculturalism, Breivik described himself as caught up in a war. Demands made by Breivik following his arrest were designed with recruitment to his cause through further publicity in mind. A lengthy manifesto construing violent action as necessary and providing relevant practical information was discovered, as well as a Facebook page with similar foci. As investigators trawled through Breivik's materials, they discovered that the extremist and mass murderer admired von Trier and thought of Dogville (2003) as one of his three favourite films.

On July $29^{\text {th }}, 2011$ the Danish daily Politiken published a piece titled 'Lars von Trier regrets "Dogville" after the Norwegian Mass Murder' (my translation); the subtitle was - 'According to Trier all of Denmark has reason for reflection. But especially Pia Kjærsgaard' (co-founder and current leader of The Danish People's Party) (Thorsen 2011). Von Trier, journalist Nils Thorsen remarked, reportedly found ready parallels between the shooting on the island of Utøya and the mass shooting that Grace (played by Nicole Kidman) instigates in the final scene of Dogville. An act of revenge, the shooting of all the inhabitants of the town of Dogville is framed by Grace as a necessary and thereby ultimately ethical act, and such phrases fit easily with the discourse that Breivik uses to justify his actions. Von Trier's position, as described by Thorsen, is, however, that as a filmmaker he 'cannot protect himself from misinterpretation.' Commenting on Breivik's references to Denmark as a model country on account of Danish policies towards Muslims, von Trier shifts the blame from the domain of cinematic expression to politics, and, more specifically, to Pia Kjærsgaard and her Danish People's Party. It is Kjærsgaard and her colleagues, von Trier claims, who have prepared the ground for actions such as Breivik's with their systematically Islamophobic discourse. As the filmmaker sees it, Breivik has misinterpreted the filmmaker, but not Pia Kjærsgaard or her Danish People's Party. Responding to von Trier's views on responsibility and blame, Pia Kjærsgaard's spokesperson Søren Espersen made pointed reference to the filmmaker's disastrous appearance at Cannes: Lars von Trier makes 'perversely violent films' and 'is a Nazi' (Christensen 2011). Espersen's legitimate point appears to be that if Hitler, Speer and others are admired on highly public occasions, and if the films depict violence without fostering attitudes that condemn it, then it is easy to be misunderstood; or, to be well understood, all depending on how one interprets von Trier's strangely insistent desire to talk about Hitler, Jews, and Nazis on occasions when such utterances have a strong sense of the 'non sequitur' about them, their relevance to the discursive context in question being very difficult to discern.

The issue raised by von Trier's 'Nazi incident,' and by his appropriation by a mass murderer, is really the one that journalist Baz Bamigboye tried to get onto the agenda in the above-mentioned exchange: responsibility. Narrative films of the kind that von Trier makes inevitably convey messages and it is by no means illegitimate to require a filmmaker to think carefully about what they are and how they might play out, which is what I take Bamigboye to have done. The frame of fiction cannot entirely exempt a director from the norms of responsible speech and expression. Inasmuch as meta-cultural pronouncements referencing directorial attitudes and beliefs are made within contexts where the protections of fiction are not operative, norms of responsible communication cannot easily be set aside. To adopt and cultivate the persona of the provocateur to the extent that von Trier does, is, in my view, ultimately irresponsible.

Von Trier, let there be no doubt about it, is an exceptionally gifted and accomplished artist whose contributions include formal innovations that have helped to develop and refine the cinematic medium's expressive possibilities. Von Trier's contributions to the world of film are not, however, limited to what he has been 
able to do with the cinematic medium, in a technical, aesthetic or formal sense. He has also, as I have argued at some length elsewhere, played an important role in pioneering a kind of gift culture - involving gifts of talent, collaboration, and reputation - that has allowed the filmmaking milieu in Denmark to flourish (Hjort 2008). There has been a tendency, in response to such incidents as the 'Nazi' ramblings at Cannes, to see von Trier as a genius artist who just tends to put his foot in it when he ventures onto a different kind of terrain. Speaking as the CEO of the Danish Film Institute, Henrik Bo Nielsen rightly condemned von Trier's statements. Such statements were not, however, seen as detracting from von Trier's status as a great artist: 'It is unfortunate that great cinema should drown in such controversy totally irrelevant to the film itself. But there's nothing new in the fact that great artists make stupid remarks' (DFI 2011).

My claim here, pace the position adopted by Bo Nielsen and others, is that von Trier is less of an artist than he could be, on account of his consistent gravitation, in his films and in his public pronouncements, toward provocation. The stance of the provocateur, as adopted by von Trier, strikes me variously as inappropriate, irresponsible, disingenuous, and incoherent. Analytic aesthetician and film scholar Berys Gaut has argued that moral concepts are anything but irrelevant in contexts of aesthetic appreciation, which also encompasses assessment of the artist's ethical attitudes and outlooks (Gaut 2007). Following this persuasive line of reasoning, von Trier diminishes himself as an artist by failing to take seriously the extent to which ethical principles and norms remain in play when ideas, including those involving make-believe, are communicated through the mass medium of film, and in various discursive sites dedicated to film.

In what follows I would like to look closely at one of von Trier's earlier films, the slave narrative Manderlay (2005), the sequel to Dogville (2003) in the 'Land of Opportunities' trilogy that will likely remain incomplete. In Manderlay some of the key problems with provocation are writ large because race is used as its central vehicle. My aim in focusing on a single film is to try to outline a pragmatics of provocation that would allow us to reject certain artistic actions for reasons to do with willful ignorance, lack of understanding, and a failure to think consequentially about cause and effect relations in relation to the inflicting of damage, hurt, or harm.

I begin by providing a brief sketch of problems arising within the context of Manderlay's production for they point to the essentially provocative and indeed explosive nature of the film's central ideas. In a second moment I attempt to extract various provocative theses from the basic plot of the film, before moving on to consider von Trier's stated intentions with the film. Finally, I consider the remarkable, indeed telling, contrast between the film's critical reception in Denmark as compared with the United Kingdom, Germany, Canada, and, of course, the United States - the main target of the film's polemics.

The film's production history clearly demonstrates that the basic premise of Manderlay - and the ideas that it communicates not only through its narrative, but through its acting styles and costumes - were seen by actors as likely to give offense. ${ }^{(5)}$ This was the case for those actors who declined roles in the film (Sydney Poitier and Harry Belafonte) as well as for those who ultimately agreed to be in it. Von Trier's ideas for Manderlay were inspired by Danish photographer Jacob Holdt, known for his book titled American Pictures and for the eponymous lecture that he bills as 'an experiment in oppression' aimed at exposing the effects of racism. ${ }^{(6)}$ During the shooting of Manderlay Holdt was summoned to the studio town of Trollhättan in Sweden, because von Trier was having 'serious problems' with actor Danny Glover, who plays Willem, the house slave, in the film. Holdt describes how he was worried about taking his 'lecture' to Trollhättan because there were many British actors in the cast:

in England my show had been a complete catastrophe ..... The London City Council had put my show in the big Scala Theater, and already on the second day there was trouble. All my equipment was knocked over and it was only salvaged because the police intervened .... The entire following week furious demonstrators penetrated the offices of the City Council, which they sprayed with boiling hot coffee. ... Black people from the West Indies in London had also been furious, as they aren't shaped and shattered by still ongoing slavery as is the case with American blacks and thus don't understand the helplessness, apathy and self-destruction I depict in American blacks. They therefore see my depictions as "racist" (Holdt 2004).

Holdt's show in Trollhättan caused an uproar on account of similar perceptions of racism on the part of the actors. Isaach De Bankolé registered his objections by refusing to participate in Holdt's experiment, while 
others (Bryce Dallas Howard) responded with pained silence, or with outspoken criticisms.

It is not easy, as non-Danish critics have remarked, to determine the precise nature of the argument in von Trier's clearly polemical, and thus inevitably argument-driven film. The film's narrative and ultimate point - whatever this may be - does, however, rest on a number of key theses, which are then variously interpreted, weighted and arranged in different instances of reception. The immediate task, then, is to extricate these central theses from the film's plot. Manderlay begins with a title informing the viewer that the story of Manderlay will be told in eight chapters. This title gives way to a black and white map of the United States with small moving rectangles tracing a path from Colorado, where the first film in von Trier's Land of Opportunities trilogy (Dogville) was set, to Alabama, where the story of Manderlay will unfold. A voice over, provided as in Dogville by John Hurt, provides reasons why Grace, her father, and his gangsters would be making their way to Alabama. The narrator's initial comments also establish the temporal parameters for the story, indicating clearly that the year is 1933. As the camera continues to zoom in on the sketch, the moving rectangles become real cars carrying people who, having alighted, begin to interact on a largely empty set resembling the Brechtian-style arrangement to which viewers were introduced in Dogville. Grace's father, now played by Willem Dafoe, is shown in conversation with one of his gangsters, and Dafoe's opening lines establish one of the film's core premises:

They will not admit it, but it's a fact. Deep down inside there isn't a woman alive who doesn't nurture these fantasies. Whether they involve harems or being hunted through the jungle by torch-bearing natives. However much they go on about civilization and democracy, sexy it ain't.

These early remarks link sex and desire to broadly barbaric and undemocratic situations, just as they implicitly connect civilization, and democracy as a putative instance thereof, to sexual repression in what is essentially a variant on recognizably Freudian themes. Grace responds with outrage to her father's statements, thereby identifying him as the provocateur and herself as the staunch defender of a civilizing project of democracy that is wholly emancipatory and entirely satisfying.

The connections posited by the Dafoe character constitute a psychosexual thesis that echoes key elements in Jean-Paulhan's introduction to Pauline Réage's Justine-like Story of O, first published in France in 1954. Paulhan's text, which is often referred to in passing as one of von Trier's sources for Manderlay, is entitled 'Happiness in Slavery' and begins by describing a putative 'Revolt in Barbados':

In the course of the year 1838, the peaceful island of Barbados was rocked by a strange and bloody revolt. About two hundred Negroes of both sexes, all of whom had recently been emancipated by the Proclamations of March, came one morning to beg their former master, a certain Glenelg, to take them back into bondage... But Glenelg, either from timidity or because he was scrupulous, or simply afraid of the law, refused to be swayed. At which point he was at first mildly jostled, then set upon and massacred, together with his family, by the Negroes, who, that same evening repaired to their cabins, their palavers, their labors, and customary rituals (Paulhan 1965: xxixxii).

Paulhan's prefatory reflections bemoan the disappearance in modern times of 'the ancient law which gives the family the power of life and death over their children', of 'corporal punishment and hazing', and of 'the old prerogative of wife-beating' and eventually conclude by insisting that the truth about the revolt was that 'the slaves were in love with their master, that they could not bear to be without him' (xxxvi). Paulhan rejects the validity of any concept of victimization, affirming instead that systematically inflicted violence can be a legitimate object of desire on the part of those against whom it is directed.

Let us consider a second highly contentious thesis developed in the film. A crucial scene early on in the film shows us Grace being summoned from her car by a black woman who refers to herself as a slave, unaware, it would appear, that slavery was abolished many decades earlier. Incensed by her newly acquired knowledge of still ongoing slavery, Grace enters the plantation, where she encounters Maam, played by Lauren Bacall. Maam dies very shortly thereafter and the aging house slave, Willem (played by Danny Glover), explains to an astonished Grace why he mourns rather than rejoices at her death: 'I'm afraid. I'm afraid of what will happen. I fear we ain't ready for a completely new way of life. At Manderlay we slaves took supper at 7 . When do free men eat?' 
Willem's fears introduce a thesis, attributable to the film's director on one view of cinematic authorship, about long-term oppression and infantilization. The idea is the familiar one, oft used in arguments aimed at delaying the collapse of empires, that democracy and the ability genuinely to desire and realize autonomy must be instilled slowly through a series of prototypically democratic practices. In the absence of such practices, the preference may well be for possibly brutal dependency, for some form of 'he-autonomy', to borrow a term from Kant. If the Dafoe character establishes an ineradicable connection between sex and barbarism, Willem's utterances foreground history, in the form of a certain kind of lived experience, as the very condition for the subjective desirability of democracy and for the competencies that this particular type of political organization requires.

A third premise emerges in the course of a conversation between Grace and her father as the latter prepares to leave the former slaves, newly enlightened and emancipated by Grace, to their own devices. Grace tells the driver to stop the car, hoping, it would seem, for some last minute show of gratitude. Her father draws parallels between her deadly insistence on liberating a pet bird when she was a six year old child - the bird died - and her most recent expression of emancipatory zeal. Grace resists the parallel, insisting that her dead Tweetie had been 'bred as an indoor bird' and 'didn't have a chance.' To the implicit claim that the former slaves do in fact have a chance, Grace's father responds as follows:

And what do you think those negroes in there are? How many generations do you think those families made their homes behind that fence? I bet you most of them have taken up employment in their former jobs with the family, contracts and all. Of course now they'll get a few dollars for their efforts, but they'll soon drink that up, and maybe they'll borrow a bit more from their employers who have no doubt opened a little store with colorful wares just for them. When push comes to shove you have just made everything far worse, as you did with Tweetie.

The thought that emancipatory efforts may exacerbate rather than enhance the situation of a given group resonates with aspects of the dependency thesis just identified. The father's rejoinders do, however, introduce another element to the philosophical picture that von Trier paints, for they highlight a series of connections between highly positive self-concepts, the opacity of motivation, and what French theorist Raymond Boudon calls perverse effects. Grace, by her father's lights, takes herself to be virtuous and knowing, yet her actions are often prompted by motivations, some of them far from admirable, that she herself misrecognizes. What is more, these actions give rise to effects that she fails to anticipate and that counter the very outcomes she purportedly had in mind. If the ethical value of an action is to be assessed in terms of its consequences, as consequentialists would have it, then it is far from clear that the actions of the self-proclaimed liberator can stand up to close scrutiny in this particular case. Careful analysis of Grace's behaviour, her father rightly anticipates, is likely to reveal arrogance, ignorance, and self-deception, as well as a stubborn defensiveness in response to diverging opinions and views.

Together the psychosexual, historical dependency, and opacity theses constitute a major part of the scaffolding for the various provocations that von Trier effects through Manderlay. Provocative in themselves, these theses become all the more so as a result of the details of their concrete manifestation in the film's developing story world. Let me illustrate this point by way of some examples that also allow me to extract the two remaining theses at play in Manderlay's conceptual scheme.

As Grace waits in the car, debating the implications of Tweetie's death with her father, Willem knocks on the window and invites her back to the plantation. Having decided to stay on the plantation and pursue her emancipatory project, Grace persuades her father to lend her a number of gangsters, including his most expert lawyer. Grace has this lawyer draw up contracts to replace the ones that Maam's family had initially proposed to the now liberated slaves. She sets up a series of workshops in which the principles of representational democracy and voting, as well as the value of community, are exemplified in various ways.

A key target for Grace's energies is Maam's book, a hand-written text that Maam had asked Grace to destroy as she lay dying. Refusing Maam's request on the grounds that the book was needed to bring her oppressive family to justice in a court of law, Grace finds herself reading and constantly objecting to the various rules and regulations that governed slave life at Manderlay. The slaves, she discovers, were divided by Maam and her family into different categories, each with their defining traits, particular forms of punishment, quotas of food, and so on. Each category carries a number as well as a description. The two most important numbers, 


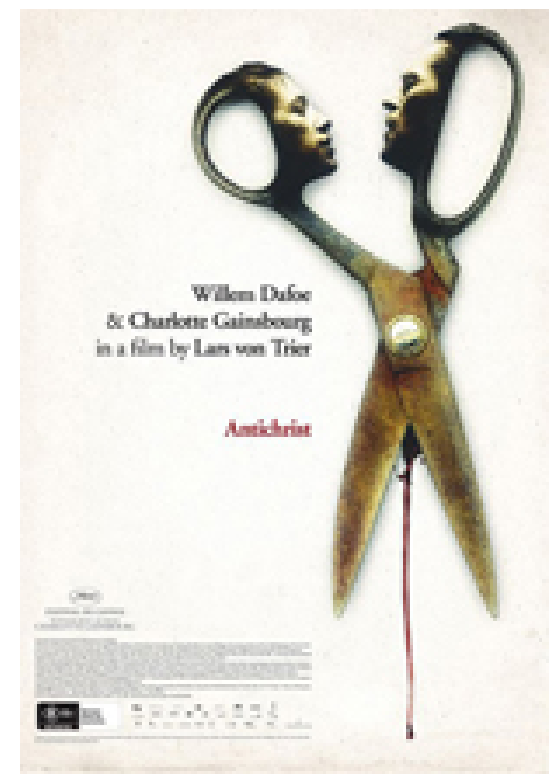

Figure 1: Antichrist (publicity poster)

both linked to a character called Timothy, are 1 and 7.1 is reserved for 'proudy niggers' and 7 for 'pleasin' niggers', the latter being glossed as a 'chameleon, a person of the kind who can transform himself into exactly the type the beholder would like to see.' Other categories identified in Maam's book include 'talkin' niggers', 'hittin' niggers', and 'clownin' niggers.'

The inherently offensive classificatory system becomes a vehicle for sustained and intense provocation as a result of its imbrication with the psychosexual, historical dependency, and opacity theses identified above. Particularly relevant in this connection are two events, the first of which concerns Grace's lust for the former slave called Timothy (whom she knows as a 'proudy nigger'), the second a stunning revelation on the part of Willem as debates concerning Timothy's true nature arise.

Let me discuss these two scenes in turn. While rejecting Maam's classificatory system as heinous, Grace in fact allows her perceptions of the former slaves to be shaped by it. Labelled as proud, Timothy (played by Isaach De Bankolé, originally from the Côte d'Ivoire) becomes the object of Grace's lust as she attributes virtues to him that are entirely consistent with pride: courage and independence of spirit, for example. Grace's erotic longings lead to a brutal sex scene, the implications of which can only be understood in terms of the contents of an earlier dream that reinforces the psychosexual thesis associated with Dafoe's character. As viewers we are given access to the contents of Grace's dream through the omniscient narrator and his ever ironic, always distanced commentary:

... the cotton seedling in her love-starved body did not give up. It manifested itself as a dream. Grace was in southern climes. There were women in exotic costumes and men in turbans. Even in her sleep she hated with a passion any idea of allowing that her father might be right. But it was a harem - a group of black slaves appeared bearing a huge charger piled with dates and in a twinkling Grace lay among the dates trembling with pleasure as a flock of Bedouins satisfied her one by one with their noses. And it was even more confusing when Timothy appeared and was both slave bearing wine... and the sheikh himself whose authoritative hands tested the size of Grace's most intimate orifices.

What we have here is a far cry from interracial desire predicated on the kind of mutuality and respect that Grace's high-minded rhetoric consistently associates with freedom. Instead the imagined sexual encounter becomes proof, in Grace's unconscious mind, of the veracity of a thesis about women and their unrecognized longing for subjugation at the hands of allegedly uncivilized people - blacks and Arabs. 
Grace's lust for Timothy converts to hatred when she discovers that he has stolen the money generated by the plantation's first harvest after Maam's death. Having at this point largely internalized the very law that she takes herself to be systematically rejecting, Grace consults Maam's book with questions in her mind about Timothy's true categorization. Studying the numbering carefully she realizes that she has mistaken a 1 for a 7, and that Timothy, rather than being a 'proudy nigger' in fact is a 'pleasin' nigger.' Full of outrage and venom, Grace anticipates the effect that her revelation of Timothy's 'true' identity will have on the group, only to discover that Willem is well aware of the thief's place within Maam's classificatory system. Timothy's numerical classification, Willem points out, can be found on page 104 of Maam's book. His detailed memory of the pages and contents of this text have a stunning but simple explanation: 'I wrote it', he says. Willem's comments on his role as author of Maam's law bring the dependency thesis into play, but also introduce a new pragmatic thesis about the relativity of evils: 'Maam and I were very young when the war ended and this new statute terrified us. We tried to imagine what kind of world would these slaves be let out into. Were they ready for it? Or, more correctly, was it ready for them?' Ongoing slavery, Willem argues, was the lesser of two evils, the freedom on offer being nothing more than a regulative ideal unlikely to be realized without conflict on an uneven field of engagement. Many of the slaves, all of those belonging to categories 2, 3, and 5 were aware of the origins of Maam's law, which they thus condoned or, stronger still, supported.

Willem's revelation quickly leads to yet another dramatic twist in the plot of Manderlay, and this twist brings another premise into play while reinforcing the idea, associated with the Dafoe character, about the opacity of mind or intention and the unintended or perverse effects of human action. In a scene that recalls the passage from Paulhan cited above, the freed slaves of Manderlay hold Grace at gunpoint and insist that she become their new Maam. When Grace responds with horror, both to the proposed enslavement and to the use of a weapon against her person, Willem quietly and pointedly remarks on the parallels with her own methods of emancipation: 'You permitted yourself to use force to convince us [about community].' What viewers are asked to reflect on is the problematic premise motivating Grace's actions, namely that the end - democracy and civilization - justifies the means - the undemocratic and uncivilized use of violence. It is worth noting in passing that Jacob Holdt encouraged von Trier and his producers to market the film in terms of its parallels with George W. Bush's operations in Iraq and the film has indeed often been discussed in those terms.

The film concludes with Grace fleeing from the plantation and with the viewer once again contemplating a simple map of the United States as the voice of John Hurt gives us ironic access to the self-deceived and now radically changed mind of the disappointed self-styled liberator: 'America was a many faceted place, no doubt about it. But not ready to accept black people? You really couldn't say that. America had proffered its hand. Discretely perhaps. But if anybody refused to see a helping hand he really only had himself to blame.' And here, then, we have a final contribution to the mix of claims that are the ingredients of Manderlay's many provocations: If Blacks are second-class citizens in America, they have only themselves to blame. Having been invited to draw this provocative inference from Grace's internal monologue, the viewer is immediately plunged into a long credit sequence that uses David Bowie's Young Americans and a wide range of images documenting black history from the days of the civil rights movements to today to achieve its polemical effects. The photographs, some of them drawn from Jacob Holdt's work, draw pointed connections between the Ku Klux Klan, Jim Crow laws, the Rodney King beating, Vietnam, the Iraq war, the murder of Till Emmett and Martin Luther King, and George W. Bush.

Manderlay's provocations are multiple, as this film lines up, not necessarily in any coherent or systematic way, one contentious thesis after the next. These theses are:

1. There are those who legitimately desire oppression.

2. Long term oppression produces subjects who lack the competencies that democracy, as the practice of freedom, requires.

3. Those who seek to occupy the moral high ground misrecognize the true nature of their motivations and give rise to effects that are at odds with the intended outcomes of their actions.

4. Slavery is in some contexts the lesser of evils.

5. The ends justify the means.

6. Blacks bear the blame for their continued marginalization in US society. ... And, finally, 
7. US history reveals a systematic exploitation of Blacks - the final message of the credit sequence.

Trier's provocations are potentially a source of harm and offense in any context where slavery is an issue. Writing as I do from Hong Kong, where incisive and probing articles calling attention to the realities of contemporary slavery are regularly published in such dailies as The South China Morning Post, it is difficult to find anything salvageable in von Trier's teasing / joking / provoking approach to the issue. His provocations, it should be clear, work on at least two levels. The first is a philosophical level where commonly held conceptions of humanity and the good can be targeted, and where the opacities of motivation, the workings of ideology, and the perverse effects of human action can be made apparent. The second level is much more specific, introducing a highly topical dimension to the provocative exercise. Manderlay, much like Dogville, works hard to bring the more general provocations to bear on a particular national target, the point being to suggest that the grand narratives of American life just might be a matter of fiction and delusion. What might be less clear is that there is a third level of provocation at work in Manderlay. With the exception of the Danish critics most critics have expressed irritation at the incoherence of the polemical argument being advanced in Manderlay, failing thereby to note that this film features a meta-provocational dimension that is designed precisely to produce this sense of frustration. Von Trier has long been interested in meta-cultural and meta-cinematic reflection, the Dogma Manifesto with its programmatic rules that both reflect on and become constitutive of every bona fide Dogma film being a clear expression of this interest.

The official Manderlay website includes the following statement by Trier: 'When I was young the medium was enough ... now one should be able to use the film for something... to raise some questions, but not to answer them.' The refusal to provide answers becomes in effect a refusal to develop a coherent argument, and the viewer is thus left to digest a series of general and topical provocations that together generate a higher-order provocation that counts as meta-cultural. The latter arises as a result of the film's willingness to dismantle the favoured beliefs of a significant number of groups in what is ultimately a purely ironic mode. Mockery combined with the refusal to commit to a position adds yet another target group to von Trier's shotgun method of provocation: those who accept that there is an important place for provocation in the world of art. The pragmatics of provocation in Manderlay works to alienate as many viewers as possible, thereby inadvertently raising a number of important questions about the moral duties of provocateurs in an increasingly fractured, crisis-ridden and globalized world where ethnicity and race are often focal points for conflict. A brief discussion of Trier's stated intentions with provocation in the Land of Opportunities trilogy help to highlight his understanding of the cinematic artist's freedom to provoke. Such a discussion also allows us to discern the limitations of a conception of artistic freedom that is entirely negative.

Von Trier's approach to the making of his Land of Opportunities trilogy suggests play and frivolity, rather than knowledge and understanding, as a legitimate basis for provocation in the current historical context. Speaking with a journalist from the Washington Post, von Trier made the following remark: 'I would like to think that it [Manderlay] would be a little more [provocative] than "Dogville",' he said, 'since it is on the issue of racism and it's about slavery, which I have found out that - and I didn't know - that it is a difficult question.' Reporting on her attempt to read this remarkable comment, Christina Talcott states: 'I searched for a note of irony in his words, but his accent clouded the usual signals' (2006). Statements by von Trier on the official Dogville website lend further support to the idea that this Danish director regards quasi-ignorance as a sufficient and perhaps even desirable condition for artistically interesting provocations:

Dogville takes place in America, but it's only America as seen from my point of view. I haven't restricted myself in the sense that I said 'Now I have to research this and this and this.' It's not a scientific film and it's not a historical film. ... Of course, it isn't the truth because I've never been there.

It might be helpful at this point to consider a specific example of the kind of knowledge that serious as opposed to frivolous provocation would entail. Harvard Law Professor Randall Kennedy provides a detailed account of how the term 'nigger' was perceived by blacks around 1930 when Manderlay's story takes place.

Referring to blacks derogatorily as niggers ... was the custom to which blacks objected most strongly. In 1939, when David O. Selznick was in the throes of producing Gone With the Wind, he received hundreds of letters from blacks warning him to remove all 'nigger' references from his upcoming film. ... Once he had been made aware of the intensity of blacks' feelings, he resolved 
to prohibit its use entirely and took pains to publicise his decision' (Kennedy 2003: 90).

On grounds having to do with plausibility, veracity, and ethics, historical research would have militated seriously against the elaboration of a purely fictional classificatory system that allows the word 'nigger' to resound, repeatedly and unrelentingly, through theatres around the world. In von Trier's approach, ignorance functions as a condition for a maximalist strategy of provocation where the single most important pay-off seems to be the thrill of provocation enjoyed by the provocateur himself.

Von Trier's repeated insistence on ignorance as a basis for provocation brings to mind one of the best selling nonfiction books of recent times, On Bullshit by the Emeritus Princeton Professor, Harry Frankfurt. A kind of discourse that can be designated by the popular term 'bullshit', claims Frankfurt, is more prevalent today than ever before for reasons that can be precisely identified. The main point, however, of his book is not to provide a cultural framework for understanding the proliferation of bullshit in contemporary life, but to define, clearly and precisely, the very concept of bullshit. An explosive response by philosopher Ludwig Wittgenstein to a casual remark made by Fania Pascal who claimed to feel 'like a dog that has been run over' (Frankfurt 2005: 24) after having had her tonsils out, allows Frankfurt to draw out the salient features of bullshit:

her fault is not that she fails to get things right, but that she is not even trying .... it is in this sense that Pascal's statement is unconnected to a concern with truth: she is not concerned with the truth-value of what she says. That is why she cannot be regarded as lying; for she does not presume that she knows the truth, and therefore she cannot be deliberately promulgating a proposition that she presumes to be false: her statement is grounded neither in a belief that it is true, nor, as a lie must be, in a belief that it is not true. It is just this lack of connection to a concern with truth - this indifference to how things really are - that I regard as of the essence of bullshit. (32-4).

Given this rather persuasive definition of bullshit, it would not be inappropriate to say that von Trier's stance as a provocateur is also that of the bullshitter par excellence. There are, of course, occasions when von Trier stridently insists that his US trilogy springs from some form of information rather than ignorance. On the official Dogville website von Trier makes the following claim: 'In my 'America' films, I mirror what information comes to me and my feelings about that information.' And when American critics objected to Dogville at Cannes, von Trier quipped: 'America is sitting on our world. I am making films that have to do with America [because] 60\% of my life is America. So I am in fact an American, but I can't go there to vote, I can't change anything. I am an American, so that is why I make films about America' (cited in Beltzer $2002 / 2005)$.

Although we may be charitable and allow that there is some extremely loose sense in which Lars von Trier is an American, it is definitely not the case that he is an African American or has any authentic access to the experience of Black Americans. What is more, while impressions mediated by the ever-globalizing efforts of American corporations and especially Hollywood may count as knowledge about certain American realities, they can hardly be said to provide an adequate basis for a serious, politically-minded and ethically-oriented provocation about race. Media culture is no substitute for serious research and its guiding principles if the goal is knowledge rather than impressionistic observations or notoriety. The question here is: if provocateurs have a moral duty to be at least knowledgeable about the agents and realities that they target, then what is to count as sufficient knowledge? Von Trier, I believe, simply sets the epistemological bar too low in a film like Manderlay.

The critical responses to Manderlay have been wildly divergent, with the film being mostly panned abroad, but tolerated and even praised in its home context, where the failings of provocation as bullshit have gone largely unnoticed. In a fascinating article entitled 'Contemporary Cinema: Between Cultural Globalisation and National Interpretation', Ulf Hedetoft highlights 'the tendency for those at the receiving end of transnational cultural processes to reinterpret and reinvent extraneous cultural influences within their own field of mental vision, their own interpretive and behavioural currency' (2000: 278). What Hedetoft insightfully demonstrates through careful consideration of various reviews of Spielberg's Saving Private Ryan is that 'national history, national territory, bounded national imaginings, [and] national 'meanings" continue to play a decisive role in cinematic reception, even in this age of Global Cinema and hybridized transnational 
productions. Even the most cursory comparison of critical responses to Manderlay in the Danish press and elsewhere brings to light a striking contrast between the sorts of things that were seen as warranting saying in Denmark as compared to other parts of the world.

Politiken, Kim Skotte

'As a work Manderlay is perfect, and as a form of cinematic expression it is marked by confidence.'

Berlingske Tidende, Ebbe Iversen

'with its unsettling combination of dramatic seriousness, moral considerations and ironic humour [Manderlay] is an unusually substantial work'

Jyllands-Posten, Kim Foss

'Trier's teasing play with clichés and stereotypes does not stop at race relations, but is brought to a philosophical and political level.'

Weekendavisen, Bo Green Jensen

'Manderlay is an outstanding film that consolidates Lars von Trier's status as an international auteur'

Information, Morten Piil

'One can only admire Manderlay for its dialectical twists and turns and for the carefully prepared points that are placed with almost mathematical precision in the overall composition.'

Ekstra Bladet, Henrik Queitsch

'[Manderlay] is consequential and ambitious beyond comparison, both at the level of content and execution.'

What we discern here is a stunning consensus that is wholly blind to issues and problems that critics located within quite different national frameworks were quick to identify. Let me provide just a few examples:

The Guardian, Gary Younge

'Von Trier's conclusions are not just simplistic; they are also insulting. The idea that African-Americans would consciously choose slavery rather than freedom doesn't even work as a metaphor.... To assert [a preference for slavery] is to deny the historical agency of Black Americans, from the underground railroads and abolitionists through to the civil rights and black power movements as they have striven not only to improve their own lot but democratize the whole country.'

The Guardian, Amina Taylor

'Manderlay was a litmus test of the film industry when it comes to black representation. The industry failed. It underlined the fact that black voices need to be more in control of telling their own stories if there is ever going to be a shift in celluloid stereotypes... His film might make interesting viewing for those who do not flinch every time they hear the 'n' word.'

The Guardian, Peter Bradshaw

'Nobody, but nobody, in the history of the world, has ever cared less about the American slaves than our snickering maestro von Trier ... [Manderlay] is simply another subversive spectacle, the subversion of which consists at least partly in its semi-seriousness: the sheer insolence of treating the subject of slavery with a jokey lack of caution. Perhaps this irreverence is valuable, perhaps not.'

The Village Voice, J. Hoberman

'The filmmaker uses Dogville's formal devices to lesser effect and his boredom is contagious.'

The Danish consensus evoked above is that Manderlay is an aesthetically successful work that courageously and probingly pursues a difficult argument. The view elsewhere is that Manderlay is cynical, mocking, puerile, irresponsible, ill informed, poorly executed, and simply offensive.

Critics writing from national contexts that are ethnically diverse as a result of long histories of immigration or colonial exploitation are finely attuned to the politics of recognition (to use philosopher Charles Taylor's influential term) that multicultural and multiethnic societies inevitably generate. These critics take issue with different aspects of Manderlay, but all write from an understanding of the ways in which cinematic representation can be caught up with precisely the forms of misrecognition that such a politics seeks to remedy. It is this kind of multicultural literacy that is lacking, both in the original film and its critical 
reception in Denmark. What is discernible instead in the Danish case is a kind of parochialism, itself the legacy of an ethnic and cultural homogeneity that has only recently begun visibly to fissure and hybridize.

There will, I hope, always be room for provocation in the world of art. The question raised by some of Denmark's more recent provocations, the infamous Cartoon Crisis (over the depiction of Mohammed), Manderlay, and von Trier's Nazi antics at Cannes is whether our current world can afford provocations that are ill-informed, purely irreverent, and ultimately monologic in the way that parochial attitudes often are. Citizenship, we know in the 'free world', involves rights and duties, and the right to freedom of cinematic expression cannot be severed from the duty to understand the likely consequences and implications of cinematic works. Von Trier has indicated that he feels compelled by the sorry state of the world to make films with a political dimension and with a connection to contemporary realities. Such a goal is no doubt admirable, but irresponsible and gratuitous provocation is not the means of achieving it. It is to be hoped that von Trier will abandon the particular form of provocation on which Manderlay relies and that, in the wake of Cannes 2011 and Norway 2011, he will think more deeply about the likely effects of his various articulations, cinematic and other. If he does not I fear that he will find himself increasingly isolated in an all-Danish ghetto, philosophically linked with or appropriated by individuals and movements with which he claims to have no genuinely held affinities.

\section{Acknowledgements}

Parts of this article were presented, in the form of a keynote, at 'Denmark and the Black Atlantic,' University of Copenhagen, 2006. I am grateful to the organizers (especially Martyn Bone) and to members of the audience (especially Leslie Gay and Candace Allen) for helpful comments. Thanks to Rod Stoneman for encouraging me to rework the piece for publication, and for thoughts about how to do it.

\section{Notes}

1. Manderlay, DVD bonus material.

2. Manderlay, DVD bonus material.

3. Manderlay, DVD bonus material.

4. 'Lars von Trier's 'Nazi' gaffe at Cannes film festival as he jokes about Adolf Hitler', http://www.youtube.com/watch?v=Lay

5. There are clear continuities between American blackface minstrelsy and the performances in Manderlay. For relevant analyses of minstrelsy and the connection between explicitly racist stage productions and later American media, see Cockrell 1997, Lhamon Jr. 1998, and Lott 1993. Spike Lee's Bamboozled is also of interest in the present context. I am grateful to Leslie Gay for these references.

6. See Holdt's official homepage for a fuller account of his book and show: http://www.americanpictures.com/english/show/index.html

\section{References}

Beltzer, Thomas. 2002. 'Lars von Trier.' Senses of Cinema 22 (addendum 2005); http://www.sensesofcinema.com/2002/greatdirectors/vontrier/

Bradshaw, Peter. 2006. 'Manderlay.' The Guardian. March 3; www.guardian.co.uk/filmandmusic/story/0,1721564,00.html

Christensen, Claus. 2011. 'Trier fortryder Dogville efter Massedrab.' EKKO July 20; http://www.ekkofilm.dk/?id=1354\&allor

Cockrell, Dale. 1997. Demons of Disorder: Early Blackface Minstrels and Their World. Cambridge:

Cambridge University Press.

Danish Film Institute. 2011. 'DFI CEO criticizes von Trier.' Film update May 19; http://www.dfi.dk/Service/English/Newsand-publications/News/May-2011/DFI-CEO-von-Triers-remarks-foolish.aspx 
Foss, Kim. 2005. 'Sort mands byrde.' Jyllands-Posten June 3.

Gaut, Berys. 2007. Art, Emotion and Ethics. New York: Oxford University Press.

Green Jensen, Bo. 2005. 'Den anden Grace.' Weekendavisen June 3.

Higgins, Charlotte. 2011. 'Lars von Trier provokes Cannes with 'I'm a Nazi' comments.' May 18; http://www.guardian.co.uk/film/2011/may/18/lars-von-trier-cannes-2011-nazi-commen...

Hjort, Mette. 2008. 'Denmark.' In The Cinema of Small Nations, eds Hjort and Duncan Petrie. Indianapolis: Indiana University Press.

2003. 'A Small Nation's Response to Globalisation.' In Purity and Provocation, eds Hjort and Scott MacKenzie. London: BFI Publications.

Hoberman, J. 2005. 'Historical Oversight: Desensitized to Cronenberg's 'Violence', jury anoints Dardennes over Jarmusch and von Trier.' The Village Voice. May 24; www.villagevoice.com/film/0521,hoberman1,64285,20.html

Holdt, Jacob. 2004. 'Julebrev [Christmas letter]'; http://www.american-pictures.com/dansk/jacob/julebrev/jul20041.htm.

Iversen, Ebbe. 2005. 'Befrieren som bøddel.' Berlingske Tidende. June 3; http://www.b.dk/film/befrierensom-boeddel

Kennedy, Randall. 2003. Nigger: The Strange Career of a Troublesome Word. New York: Vintage Books.

Lhamon Jr., W. T. 1998. Raising Cain: Blackface Performance from Jim Crow to Hip Hop. Cambridge, MA: Harvard University Press.

Lott, Eric. 1993. Love and Theft: Blackface Minstrelsy and the American Working Class. New York: Oxford University Press.

Paulhan, Jean. 1965. 'Happiness in Slavery.' In The Story of O, Pauline Réage, translated by Sabrine d'Estrée. New York: Grove Press.

Piil, Morten. 2005. 'Slaveriets mentalitet.' June 3; http://www.information.dk/107067

Queitsch, Henrik. 2005. Ekstra Bladet June 3.

Skotte, Kim. 2005. 'Et helstøbt værk.' Politiken June 3; http://ibyen.dk/film/anmeldelser/ECE114817/ethelstoebt-vaerk/

Stoneman, Rod. 2009. 'Reviewing Antichrist.' Film Ireland Online 130; http://www.filmireland.net/2009/09/01/issue130-\%E2\%80\%93-reviewing-antichrist/

Talcott, Christina. 2006. 'Von Trier, Mapping 'Manderlay.' Washington Post February 17; http://www.highbeam.com/doc/1F 94344.html

Taylor, Amina. 2006. 'Trial and Error.' The Guardian. February 27; film.guardian.co.uk/features/featurespages/0,1718805,00

Thorsen, Nils. 2011. 'Lars von Trier fortryder 'Dogville' efter det norske massemord. Ifølge Trier har hele Danmark grund til selvransagelse. Men især Pia Kjærsgaard.' Politiken July 29; http://politiken.dk/kultur/film/ECE1349365/lars-von-trier-fortryder-dogville-efter-det-norske-massemord/

Urban, Greg. 2001. Metaculture: How Culture Moves Through the World. Minneapolis: University of Minnesota Press.

Walker, John A. 1999. Art $\&$ Outrage: Provocation, Controversy and the Visual Arts. London: Pluto Press.

Younge, Gary. 2006. 'Liberty? No Thanks.' The Guardian. February 24; http://www.guardian.co.uk/film/2006/feb/24/1 


\section{Author Information}

Mette HJORT is Chair Professor and Head of Visual Studies at Lingnan University in Hong Kong, Affiliate Professor of Scandinavian Studies at the University of Washington, Seattle, and Honorary Professor at the Center for Modern European Studies, University of Copenhagen. She has published a number of books, most recently Lone Scherfig's Italian for Beginners, The Danish Directors 2 (with Eva Jørholt and Eva Novrup Redvall), and The Cinema of Small Nations (with Duncan Petrie). 